\title{
Зримая история Тувы \\ в фотодокументах Национального архива Республики Тыва
}

\author{
Руслана Н. Базыр \\ Национальный архив Республики Тыва, Российская Федерация
}

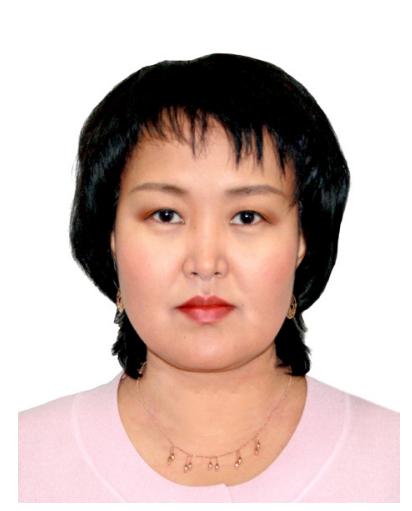

В статье проанализирован состав фотодокументов Национального (до 07.04.2020 2.Государственного) архива Республики Тыва, произведена их классификация, дана подробная характеристика основных коллекций. В архиве хранятся 4466 негативов-оригиналов, 5115 позитивных отпечатков, из которых 1832 фотоотпечатка сформированы в 24 тематических альбома, а также 95 единиц учета (файлов), записанных на компакт-дисках.

Прием фотодокументов в архиве осуществлялся с 1989 г. Основные источники пополнения: организации республики, граждане. Также архив собирает путем инициативного документирования. Классификация фотодокументов проведена по функциональному (целевому) назначению, по цвету изображения, по материальной основе носителя и пр. Также документы можно разделить на событийные фотографии (около 35\%); портретные фотографии (около 39\%); видовые фотографии, определенные предметы на местности и т. д. (около 25\%). Наиболее востребованными являются фотодокументы периода Урянхайского края (1914-1921) и Тувинской Народной Республики (1921-1944), входящие в состав нескольких фондов.

Более известны фотодокументы архивного фонда «Коллекция фотодокументов по истории Тувы» (1913-1940 г2.) краеведа В. П. Ермолаева. Но есть также много фотодокументов государственных деятелей, рядовых тружеников, а также людей, внесших существенный вклад в развитие республики. Все они являются важными источниками изучения истории Тувы.

Текст статьи иллюстрирован рядом фотографий из фондов архива.

Ключевые слова: фотодокумент; фотография; архивный документ; Государственный архив Республики Тыва; Национальный архив Республики Тыва; Владимир Петрович Ермолаев; история Тувы; Тува; Тувинская Народная Республика

\section{Для цитирования:}

Базыр Р. Н. Зримая история Тувы в фотодокументах Национального архива Республики Тыва // Новые исследования Тувы. 2020, № 2. С. 47-62. DOI: www.doi.org/10.25178/nit.2020.2.3

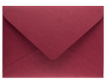

Базыр Руслана Николаевна - заместитель директора Национального архива Республики Тыва. Адрес: 667010, Россия, г. Кызыл, ул. Кечил-оола, д. 91. Тел.: +7 (394-22) 5-63-15. Эл. адрес: rnb-х@mail.ru ORCID ID: 0000-0002-5305-3275

Bazyr Ruslana Nikolaevna, Deputy Director, National Archives of the Republic of Tuva. Postal address: 91 Kechil-ool St., 667010 Kyzyl, Russian Federation. Tel.: +7 (394-22) 5-63-15.E-mail: rnb-x@mail.ru 


\title{
Visible history of Tuva in photo documents at the National Archives of the Republic of Tuva
}

\author{
Ruslana N. Bazyr \\ National Archives of the Republic of Tuva, Russian Federation
}

\begin{abstract}
The article analyzes the photographic collections at the National Archives of the Republic of Tuva (prior to 07.04.2020 known as the State Archives of RT. We have provided a classification and in-depth description of the main collections, which include photographs. The archives store 4,466 master negatives, 5,115 positive prints, of which 1,832 in thematic albums. Finally, 95 archival units (files) are recorded onto CD-ROMs.

The archives have been providing an option to submit photographs since 1989, with the bulk of them coming from regional organizations and private individuals. The archives also practice proactive collecting of photodocuments. Our classification runs along the lines of functional purpose, of the image colo, and of the material of the carrier, among other factors. Documents can thus be classified into photographs of events (about 35\%); portrait photography (about 39\%); and landscape photos or those featuring certain items on the ground (about 25\%). The most popular among the photodocuments are those which belong the period of the Uriankhai Territory (1914-1921) and the Tuvan People's Republic (1921-1944). They are scattered among several collections.

Even better known are the photodocuments belonging to the fond titled "A collection of photographs related to the history of Tuva" (1913-1940) taken by ethnographer V. P. Ermolaev. Beside these, the collections hold many photographs of both public figures, ordinary workers and people who have made a significant contribution to the development of the region. All of these are important sources for studying the history of Tuva.

The text of the article is illustrated with several photographs from the collections of the Archives.
\end{abstract}

Keywords: photo document; photograph; archival document; State Archives of the Republic of Tuva; National Archives of the Republic of Tuva; Vladimir Petrovich Ermolaev; history of Tuva; Tuva; Tuvan People's Republic

Bazyr R. N. Visible history of Tuva in photo documents at the National Archives of the Republic of Tuva. The New Research of Tuva, 2020; 2: 47-62. (In Russ.). DOI: www.doi.org/10.25178/nit.2020.2.3

\section{Введение}

Национальный архив Республики Тыва (Государственный архив Республики Тыва, ГА РТ¹) является старейшим учреждением в республике. За все время своего 90-летнего существования (с 23 июня 1930 г.) Государственный архив РТ собрал в своих стенах документальные материалы с конца XVIII века по настоящее время. Все документы, поступившие на государственное хранение, прошли тщательный отбор опытными специалистами отдела комплектования, ведомственных архивов и делопроизводства, членами экспертно-проверочной комиссии Министерства культуры Республики Тыва, большинство из которых составляют сотрудники архива с многолетним стажем работы. На данный момент в учреждении находится 275071 единица хранения в 1435 архивных фондах, 125 из которых составляют коллекции фотодокументов.

Фотодокумент - это документ, созданный фотографическим способом. Появление фотодокументов относится к первой половине XIX века и связано с изобретением фотографии. С тех пор она стала неизбежным спутником в жизни человека. Без нее невозможно представить себе ни одной отрасли человеческой деятельности, ценность фотодокументов связана и с тем, что они возникают в момент событий и на месте событий. Наконец, фотодокументы не только несут информацию о реальной действительности, но и оказывают эстетическое воздействие на человека (Ларьков, 2006: 37-38).

\footnotetext{
${ }^{1}$ В связи с тем, что переименование архива пришлось на период предпечатной подготовки статьи (7 апреля 2020 г.) далее мы сохраняем в тексте старое название "Государственный архив Республики Тыва" и аббревиатуру "ГА РТ". - ред.

Editors' note: Since the Archives was renamed while editorial work on the article was already under way (April 7, 2020), we have preserved at some places the institution's old name - "State Archives of the Republic of Tuva".
} 
В. М. Магидов называет некоторые отличительные особенности фотодокумента: способность фиксировать лишь одно мгновение снимаемого объекта, нередко регистрируя мельчайшие детали происходящего процесса, приравнивая фотодокумент к одному кинокадру; возможность посредством информации, заключенной в фотодокументе, не только образно представить событие, но и осмыслить его с учетом своеобразия передачи движения в фотографии, ее композиционной, пространственно-временной целостности, использования различных приемов съемки; наличие разнообразия информации, заключенной в фотодокументе, создает возможность интегрированного представления о действительности, причем этот процесс осуществляется в наиболее активной для восприятия форме (Магидов, 1992: 107). Эти специфические черты фотодокументов делают их незаменимыми источниками при исследовании истории страны, республики, конкретного народа.

В этой связи возникает необходимость в изучении коллекций фотодокументов Государственного архива Республики Тыва, которые до настоящего времени не исследовались.

Большого внимания в этом плане удостоились только коллекции фотодокументов В. П. Ермолаева ${ }^{1}$, находящиеся как в Государственном архиве РТ, так и в Национальном музее РТ. Например, Б. В. Мунге анализирует содержание фотоальбомов П. В. Ермолаева, дает сведения об использовании работ известного фотографа Тувы в подготовке фундаментальных трудов и повседневной архивной работе (Мунге, 2019). А. М. Дугар-Сюрюн описывает фотодокументы из 7 фотоальбомов Ермолаева с 1925 по 1940 гг. (Дугар-Сюрюн, 2013). Е. А. Айыжы, М. М. Мандан-Хорлу, А. Ч. Монгуш провели более масштабную работу по систематизации коллекции по тематическому принципу, проанализировали проблемы атрибуции и сохранения коллекции фотографа (Айыжы, Мандан-Хорлу, Монгуш, 2019ab). А. О. Дыртыкоол изучила фотографии В. П. Ермолаева, посвященные творчеству первых артистов тувинского театра (30 единиц хранения) и описала самые значимые из них (Дыртык-оол, 2019). Интересен также ее обзор фотоиллюстраций Ермолаева, включенных в фундаментальные труды ученых Тувы (Дыртык-оол, 2013). О. Ю. Иргит рассматривает вопросы привлечения фотографий В. П. Ермолаева из фондов Национального музея РТ в качестве источников по истории политических репрессий в Туве (Иргит, 2019: 176-180). М. О. Дыртык-оол изложила последовательность научного описания фотонегативов; она рассмотрела некоторые научные паспорта на фотонегативы В. П. Ермолаева, краткие аннотации к фотографиям самого автора (Дыртык-оол, 2013). О. О. Монгуш составила количественную характеристику фотоальбомов по негативам В. П. Ермолаева (Монгуш, 2013). М. М. Мандан-Хорлу провела сопоставление снимков В. П. Ермолаева с его исторической публицистикой. Автор определила В. П. Ермолаева как первого специалиста в области визуальной антропологии в Туве (Мандан-Хорлу, 2019).

Столь многочисленные исследования творчества В. П. Ермолаева объясняются тем, что он являлся одним из первых профессиональных фотографов в Туве, отразившим в своих работах исторические события, происходившие в Урянхайском крае, Тувинской Народной Республике, Тувинской автономной области РСФСР. Его коллекция фотодокументов занимает значительное место в Государственном архиве Республики Тыва и насчитывает 1572 фотоотпечатка.

Остальные фотоколлекции архива до настоящего времени не являлись объектом специальных исследований. В данной статье впервые проведен анализ фотодокументов Государственного архива Республики Тыва, произведена их классификация, дана подробная характеристика основных коллекций, в состав которых входят фотодокументы, тематическое содержание которых отражает основные события истории Тувы XX века.

\section{Комплектование ГА РТ фотодокументами}

Государственный архив Республики Тыва по праву гордится своим собранием фотодокументов небольшим, но достаточно значимым по содержанию. В распоряжении архива имеются 4466 негативов-оригиналов, 5115 позитивных отпечатков, из которых 1832 фотоотпечатка сформированы в 24 тематических альбома, а также 95 единиц учета (файлов), записанных на компакт-дисках.

Все фотодокументы архива систематизированы в коллекции и включены в описи фотодокументов. На фотоколлекции ведется список, отдельный от списка фондов, с самостоятельной порядковой нуме-

\footnotetext{
${ }^{1}$ Ермолаев Владимир Петрович (1892-1982) - российский этнограф, исследователь, первый директор Тувинского музея. В течение 45 лет по особой программе вел систематические фотосъемки природы Тувы, быта ее населения, занятий, промыслов, различных моментов общественной и государственной жизни.
} 
рацией; прием фотодокументов фиксируется в отдельной книге - «Книге учета поступлений фотодокументов». Такой способ фондирования существенно облегчает выявление, поиск и выдачу фотодокументов пользователям, нежели их рассредоточение среди других фондов.

Отбор фотодокументов осуществляется на основании следующих нормативных документов: Федерального закона от 22 октября 2004 г. № 125-ФЗ «Об архивном деле в Российской Федерации»; Закона Республики Тыва от 13 июля 2006 N 1893 BX-I «Об архивном деле в Республике Тыва»; Правил организации хранения, комплектования, учета и использования документов Архивного фонда Российской Федерации и других архивных документов в государственных и муниципальных архивах, музеях и библиотеках, организациях Российской академии наук, утвержденных приказом Министерства культуры и массовых коммуникаций Российской Федерации от 18 января 2007 г. № 19; Основных правил работы государственных архивов с кинофотодокументами, утверждённых Главным архивным управлением при Совете Министров СССР от 21 мая 1979 г. (с изм. от 29.12.2001); Регламента работы экспертно-проверочной комиссии при Министерстве культуры Республики Тыва, утвержденного приказом Министерства культуры Республики Тыва от 26 февраля 2019 г. № 150.

Систематический учет приема фотодокументов в ГА РТ начали вести только с 1989 г. в связи с созданием фотофонда. И те фотографии, которые поступали до этого времени, в «Книге учета поступлений фотодокументов» зафиксировали за 1989 г. Поэтому за этот год количество принятых фотодокументов насчитывает 621 единицу хранения. В последнее десятилетие (с 2010 по 2019 гг.) архив стал уделять больше внимания работе с фотофондом в связи с возросшим интересом исследователей к фотодокументам. Мы составили диаграмму поступлений фотодокументов за это время. Откуда видно, что поступление фотодокументов происходило сравнительно стабильно, кроме 2010 и 2014 гг., что связяно с созданием таких объемных коллекций, как «Сельское хозяйство» (ГА РТ, ф. 39, оп. 1 (фотодокументы (далее - ф/д)), «Спорт» (ГА РТ, ф. 26, оп. 1 (ф/д)), «Участники Великой Отечественной войны 1941-1945 гг.» (ГА РТ, ф. 50, оп. 1 (ф/д)).

Поздний учет фотодокументов, на наш взгляд, был связан с отсутствием специального работника, который занимался бы экспертизой ценности и упорядочением фотодокументов, также в связи с нехваткой кадров и загруженностью специалистов отдела комплектования.

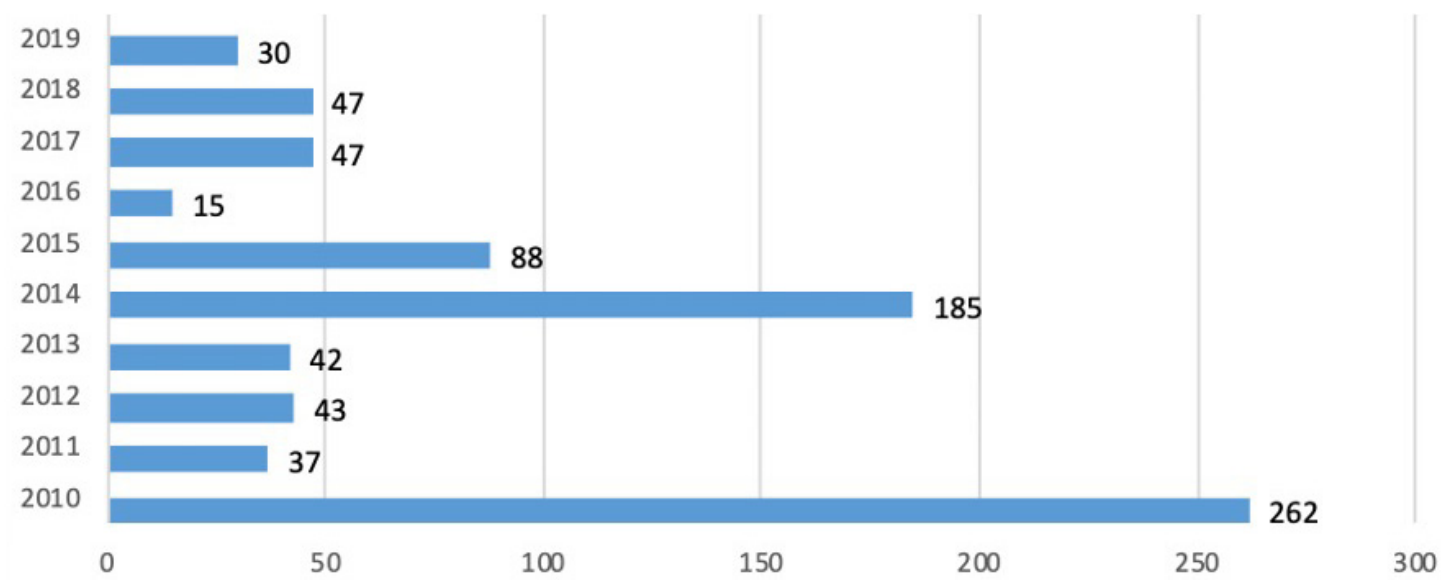

Диаграмма 1. Прием фотодокументов в ГА РТ с 2010 г. по 2019 г., в ед. хр. Diagram 1. Photographic documents submitted to SA RT, 2010 to 2019, archival units.

Фотодокументы поступают на постоянное хранение в архив на безвозмездной основе от организаций республики, граждан (собственников или владельцев фотодокументов), а также путем инициатив-

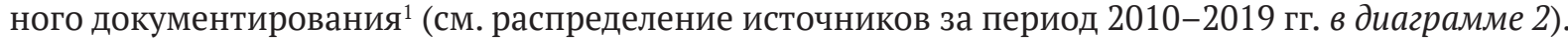

\footnotetext{
${ }^{1}$ Инициативное документирование - это процесс, при котором архивы проводят документирование событий с применением собственных средств. Созданные при этом фотодокументы принимаются на хранение в установленном порядке. Данный вид документирования нормативно закреплен в Правилах организации хранения, комплектования, учета и использования документов Архивного фонда Российской Федерации и других архивных документов в государственных и муниципальных архивах, музеях и библиотеках, организациях Российской академии наук (2007 г.), в п. 4.4.4. [Электронный ресурс] // Федеральное архивное агентство. URL: http://archives.ru/documents/methodics/OAD/data/attachments/pravila.pdf
} 


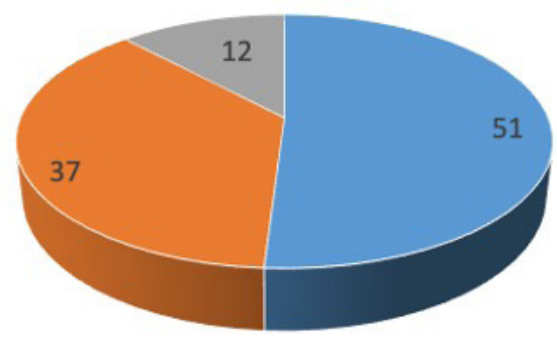

" От организаций -От граждан = Инициативное документирование

Диаграмма 2. Соотношение объемов из разных источников, в \% (с 2010 г. по 2019 г.). Diagram 2. Percentage of submissions from various sources, 2010 to 2019.

В настоящее время именно фотодокументы организаций составляют основу пополнения коллекции фотодокументов архива, особенно фотодокументы органов законодательной, исполнительной власти и учреждений культуры Республики Тыва. Второе место среди источников по пополнению коллекции архива занимают личные архивы граждан. Третье место занимают фотодокументы, полученные в результате инициативного документирования. Самостоятельно запечатлевать на фото современные мероприятия Тувы, имеющие историческое значение, к сожалению, специалисты архива не могут в связи с отсутствием профессиональной аппаратуры.

В 1990 и 1998 гг. в архиве проводились съемки наиболее ценных архивных документов, статей из газет, фотографий, хранящихся в ГА РТ, а также в личных коллекциях граждан и других архивах. Около 160 копий, сделанных методом фотографирования и последующей печати на фотобумаге (далее фотокопии), находятся в таких коллекциях, как «Копии архивных документов» (ГА РТ, ф. 29, оп. 1 (Ф/д)), «Красные партизаны» (ГА РТ, ф. 45, оп. 1 (ф/д)), «Пальмбах Александр Адольфович (1897-1963), тюрколог, один из основателей тувинской письменности» (ГА РТ, ф. 47, оп. 1 (ф/д)), «Рушева Надежда Николаевна (1952-1969)» (ГА РТ, ф. 91, оп. 1 (Ф/д)), «Участники Армейского Совета партизанской армии Кравченко-Щетинкина» (ГА РТ, ф. 118, оп. 1 (ф/д)) и в др.

При отборе фотодокументов сначала проводится предварительная атрибуция фотодокументов, чаще всего дома у гражданина или в организации. Экспертиза ценности, упорядочение и подготовка к передаче на постоянное хранение осуществляется специалистами уже в архиве. Важным аспектом при проведении атрибуции и экспертизы ценности является наличие пометок, надписей автора, владельца, представляющих собой краткое изложение сведений о событиях, предметах, лицах, изображенных на фотодокументе, месте и дате съемки. Нередко специалистами ГА РТ проводятся разъяснительные работы частным лицам, представителям организаций, передающим фотодокументы в архив, о необходимости наличия текста пояснительного характера, без которого фотодокумент теряет свою ценность, и, при возможности, текстовой сопроводительной документации в виде воспоминаний, статей, репортажей и т. д. Фотодокументы без аннотаций в архив не принимаются.

Проблема с неаннотированными фотодокументами стоит перед сотрудниками архива давно. В учреждении имеются неописанные фотоальбомы, фотоотпечатки и негативы, переданные в архив потомками или третьими лицами в 1990-х - в начале 2000-х гг. Документов, подтверждающих факт приема-передачи, нет. Несмотря на то, что фотодокументы не описаны и официально не переданы на государственное хранение, они бережно хранятся специалистами отдела государственного учета и обеспечения сохранности архивных документов. Попытки установления источниковедческой ценности этих фотодокументов проводились не раз. Некоторые снимки удалось атрибутировать, но большинство из них остались нераскрытыми.

При визуальном осмотре фотографий видно, что они относятся к разным периодам: временам Тувинской Народной Республики (ТНР), Тувинской автономной области (ТАО) и раннему периоду Тувинской АССР. На них запечатлены события общественной, спортивной, культурной жизни тувинцев, особый интерес вызывают фотографии из жизни простых аратов ${ }^{1}$, а также два альбома с фотографиями государственных деятелей ТНР, собранных археографом Центрального государственного архива Республики Тыва Н. Л. Кунчуном в 1988 г.

\footnotetext{
${ }^{1}$ Одна из подобных фотографий использована для обложки номера. - ред.
} 
В альбомы Н. Л. Кунчуна вошли фотографии не только государственных деятелей, тувинских добровольцев, но и рядовых граждан, внесших весомый вклад в различные сферы жизни молодой республики. Для атрибуции фотодокументов специалистами архива не раз проводилось интервьюирование старейшин республики, потомков тувинских добровольцев, историков и краеведов. Благодаря этому большинство неизвестных лиц на снимках удалось идентифицировать, но время и место создания, авторство снимков, оригинальность или копийность установить не удалось и, к сожалению, уже не удастся. Также вызывает некоторые сомнение достоверность некоторых установленных имен и фамилий, особенно малоизвестных людей. Для ее подтверждения архивистам в дальнейшем необходимо провести сравнительный источниковедческий анализ фотодокументов Государственного архива Республики Тыва с фотодокументами из фондов Национального музея им. Алдан-Маадыр Республики Тыва, с книжными изданиями, справочной литературой и др.

Итак, мы видим, что по общим критериям оценки фотодокументов, коими являются критерии происхождения, содержания и внешних особенностей документов, вышеупомянутые фотодокументы можно отнести в разряд «не выдерживающих никакой экспертизы», но с точки зрения ценности содержания изображений, безусловно, представляют интерес для современного общества.

\section{Характеристика коллекций фотодокументов}

В соответствии с классификацией Н. Н. Кушнаренко (Кушнаренко, 2006: 375-376), фотодокументы Государственного архива Республики Тыва можно охарактеризовать следующим образом:

- по функциональному (целевому) назначению фотодокументы относятся к фотографиям общего назначения - документальным и любительским;

- по цвету изображения - в основном черно-белые, за исключением фотографий последнего десятилетия, в процентном соотношении цветные фотографии составляют $2,4 \%$ от общего числа фотодокументов;

- по виду подложки и материальной основе носителя - фотографии на гибкой полимерной (пленочном негативе) и бумажной основе (фотобумаге);

- фотографии листовые (карточные) различной длины и ширины;

- основными материальными носителями фотодокументов являются пленка и бумага, и всего 0,02\% составляют современные носители - компакт-диски, на которых хранятся 95 файлов - единиц учета.

Опираясь на вспомогательную классификацию, предложенную Н. В. Мандральской, мы выявили, что фотодокументы архива по содержанию можно разделить на событийные фотографии (около 35\%); портретные фотографии (около 39\%); также на видовые фотографии, запечатлевшие местность, где проходило то или иное событие, определенные предметы на местности и т. д. (около 25\%) (Мандральская, 2010: 260). Данная классификация может быть практически полезной для исследования настоящего и прошлого республики.

Наиболее востребованными являются фотодокументы периода Урянхайского края (1914-1921) и Тувинской Народной Республики (1921-1944), которые входят в состав следующих коллекций:

ф. 1 «Члены ТНРП» за 1925-1943 гг.,

ф. 2 «Торговля» за 1934-1935, 1972 гг.;

ф. 6 «Женщины Тувы» за 1930-1977 гг.;

ф. 8 «С. К. Тока - первый секретарь Тувинского Обкома КПСС» за 1935-1970 гг.;

ф. 9 «Санатории, целебные источники в Туве» за 1926-1959 гг.;

ф. 19 «Тувинские добровольцы - участники Великой Отечественной войны» за 1938-1985 гг.;

ф. 22 «Передовики производства периода ТНР» за 1926-1991 гг.;

ф. 23 «Ветераны Великой Отечественной войны» за 1942-1985 гг.;

ф. 24 «Здравоохранение» за 1924-1976 гг.;

ф. 36 «Писатели» за 1934-1983 гг.;

ф. 39 «Сельское хозяйство» за 1926-1984 гг.;

ф. 45 «Красные партизаны» за 1917-1977 гг.; 
ф. 47 «Пальмбах Александр Адольфович (1897-1965) - тюрколог, один из основателей тувинской письменности» за 1930-1961 гг.;

ф. 49 «Члены Малого Хурала Тувинской Народной Республики из Тоджинского района» за 1935 г.;

ф. 62 «г. Кызыл - столица Тувинской АССР» за 1914-1980 гг.;

ф. 72 «Первый военный летчик Тувы Кидиспей (Чооду) Василий Дагбаевич» за 1934-1947 гг.;

ф. 101 «Коллекция фотоальбомов по истории Тувы», автор В. П. Ермолаев, 13 фотоальбомов за 1913-1940 гг.;

ф. 117 «Советско-тувинское акционерное транспортное общество "Совтувтранс"» за 1933-1937 гг.;

ф. 118 «Участники Армейского Совета партизанской армии Кравченко-Щетинкина» за 1918-1968 гг.

\section{Коллекция В. П. Ермолаева}

Необходимо особо выделить фотодокументы архивного фонда «Коллекция фотодокументов по истории Тувы» за 1913-1940 гг. (ГА РТ, ф. 101, оп. 1 (ф/д)). Автором коллекции является энтузиасткраевед Владимир Петрович Ермолаев, принимавший непосредственное участие в создании Тувинского краеведческого музея. С 1929 по 1934 гг. В. П. Ермолаев был первым его директором, с 1927 г. являлся действительным членом Красноярского отдела Государственного географического общества, с 1965 г. - членом Союза журналистов СССР. В течение 45 лет он вел систематические фотосъемки природы Тувы, быта ее населения, его занятий, промыслов; различных моментов общественной и государственной жизни (Дыртык-оол, 2012).

В коллекцию Государственного архива РТ вошли 1572 фотоотпечатка, сформированные по тематическому содержанию в 13 фотоальбомов:

1) «История Тувы. Природа» за 1915-1938 гг.;

2) «Природа - реки, горы, озера. Фотографии по истории Тувы, боги тувинского народа» за 1915-1940 гг.;

3) «О быте тувинского народа» за 1916-1936 гг.;

4) «Животноводство в Туве» за 1913-1935 гг.;

5) «Сельское хозяйство и земледелие ТНР» за 1916-1940 гг.;

6) «Торговля, промыслы, транспорт» за 1913-1937 гг.;

7) «Торговля и промышленность» за 1913-1935 гг.;

8) «Транспорт, дороги» за 1916-1935 гг.;

9) «Демонстрации, парады. Животноводство» за 1913-1938 гг.;

10) «Парады, съезды, заседания, демонстрации, митинги» за 1928-1936 гг.;

11) «г. Кызыл» за 1925-1939 гг.;

12) «15-летие ТНР. Праздничные митинги, парады» за

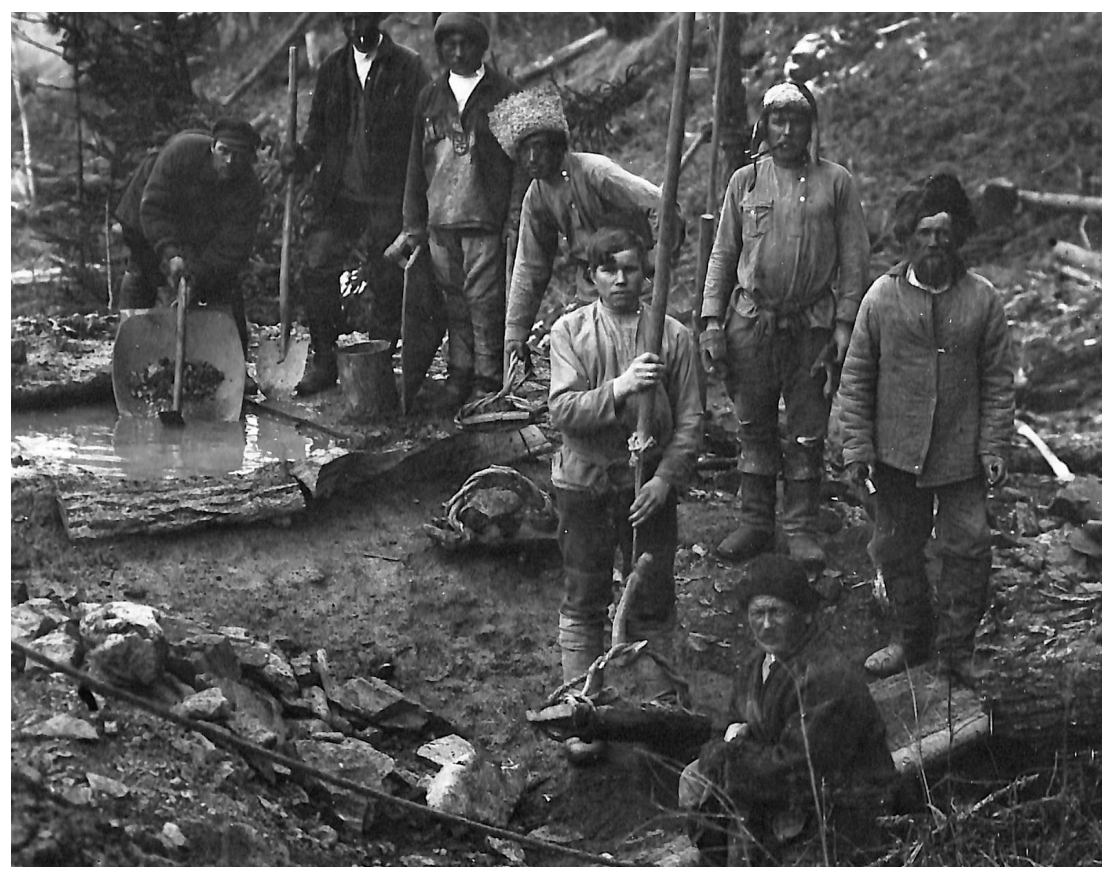

Фото 1. Артель старателей на прииске «Харал». Фото В. П. Ермолаева, 1925 г.

Из фондов Государственного архива Республики Тыва. Photo 1. A crew (artel') of miners at the Haral mine.

Photo by V. P. Ermolaev, 1925. (SA RT). 1931-1936 гг.;

13) «Строительство автомобильной дороги «Кызыл - Абакан» за 1933-1936 гг.

Фотографии Ермолаева отражают изменения, которые происходили в Туве в начале XX века, например, на фотографии, датируемой 1925 г., - развитие золотого горного промысла в Туве (фото 1). Проникновение золотого промысла на территорию Тувы, по данным Н. М. Молерова и В. Д. Март-оола, началось в конце 1830-х гг. (Молеров, Март-оол, 2013: 104, 168). 


\section{НОВЫЕ ИССЛЕДОВАНИЯ ТУВЫ}

www.nit.tuva.asia
THE NEW RESEARCH OF TUVA

2020

Novye issledovaniia Tuvy

Ермолаеву, как бывшему фотографу почвенно-ботанической экспедиции Красноярского краеведческого музея, было свойственно точное написание наименований мест съемок пейзажей. Например, на фото 2 рукой автора сделана надпись: «Енисей. Большой порог, справа часовня». Здесь изображен Большой (Хутинский) порог на реке Бий-Хем (Большой Енисей), справа - часовня. В коллекции имеется около шести фотографий Большого (Хутинского) порога на реке Бий-Хем, сделанные им в разные годы. Благодаря Ермолаеву до нас дошли изображения порога в первозданном виде, еще не тронутом рукою человека (Владимир Петрович Ермолаев ..., 2012: 148). Сейчас Хутинский порог является памятником природы регионального значения, протяженностью 1,3 км.

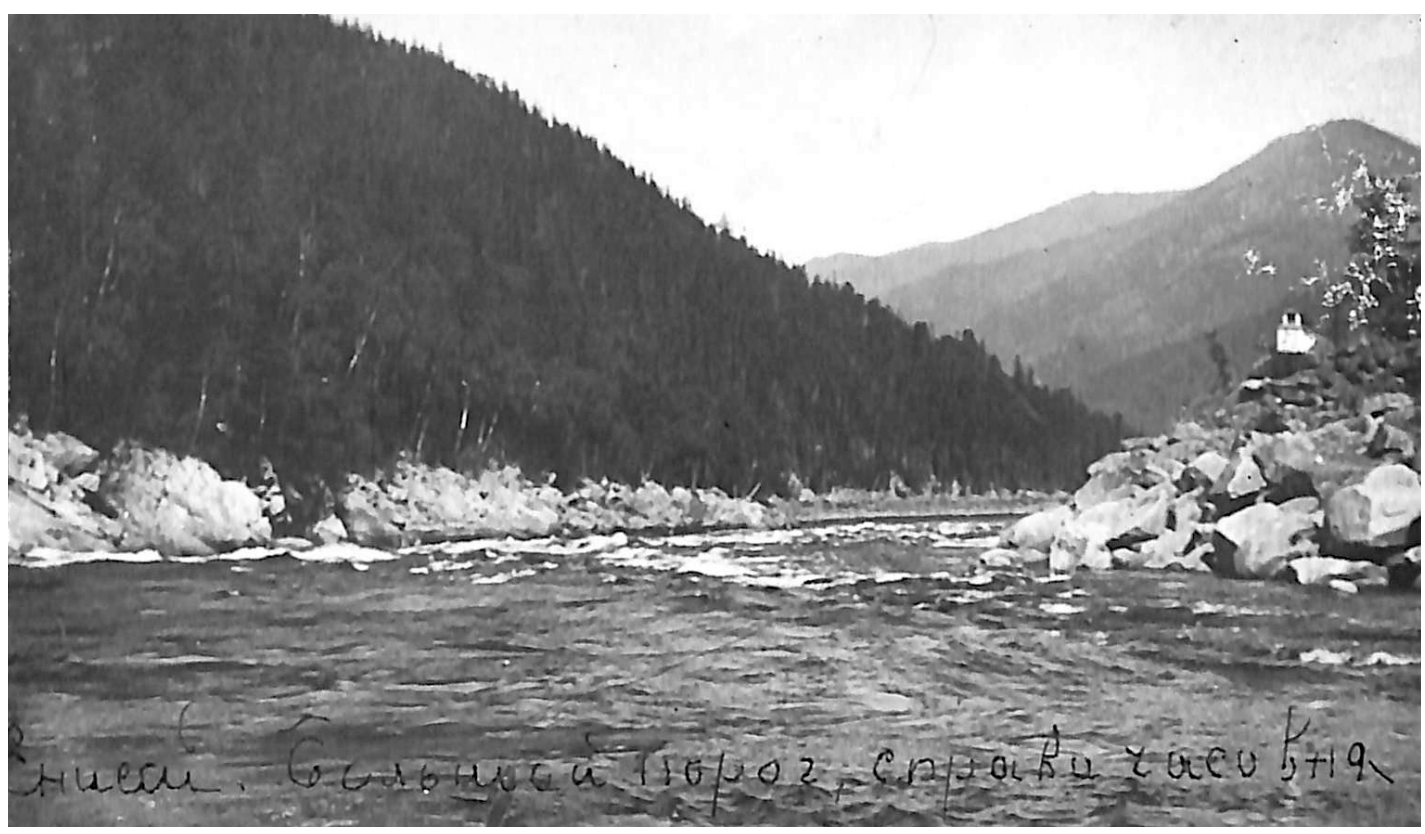

Фото 2. Большой порог на реке Енисей. Фото В. П. Ермолаева, 1930 г.

Из фондов Государственного архива Республики Тыва.

Photo 2. Large rapids on the Yenisei River. Photo by V. P. Ermolaev, 1930. (SA RT).

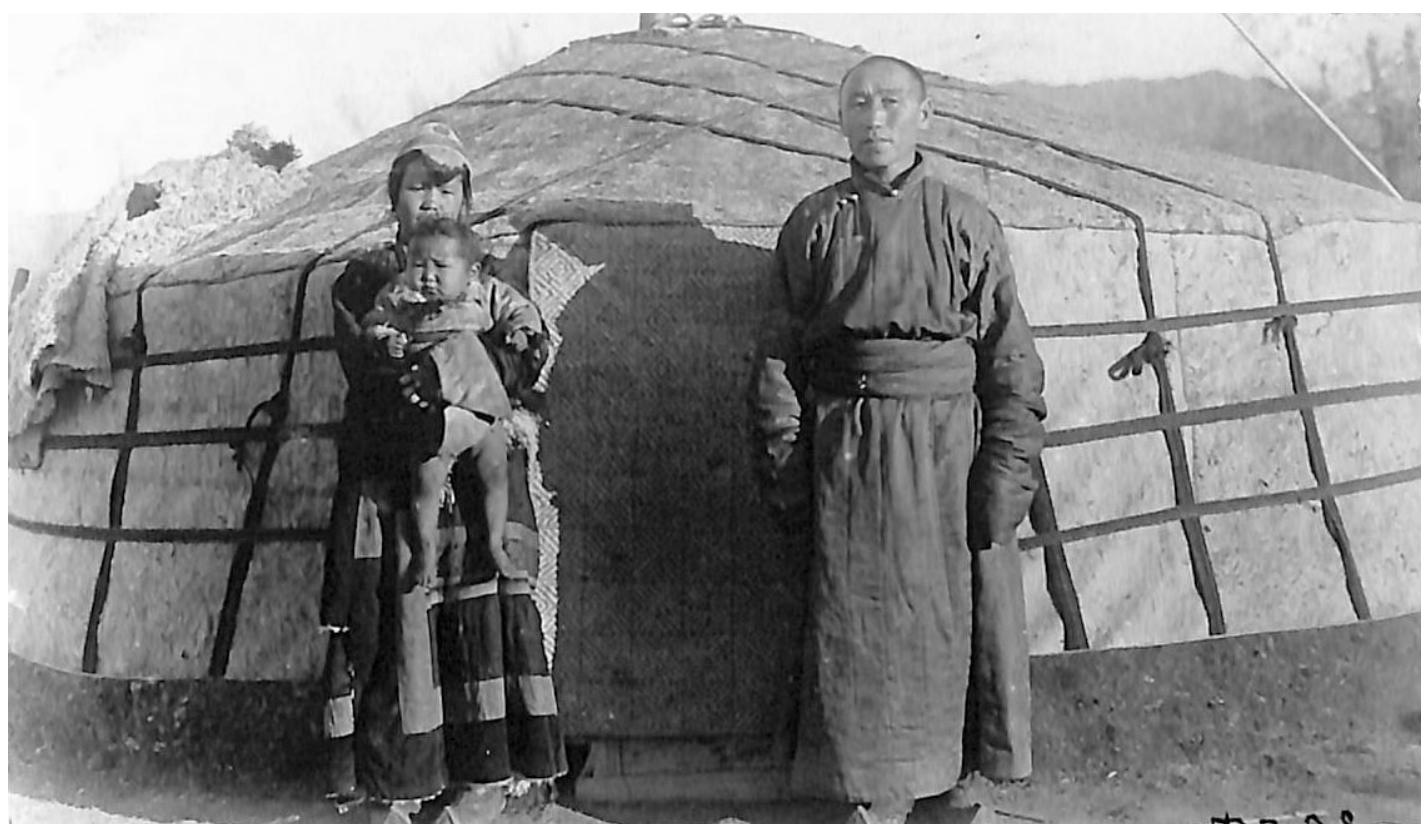

Фото 3. Адыг-Тюлюш Хемчик-оол с женой и ребенком. Фото В. П. Ермолаева, 1928 г. Из фондов Государственного архива Республики Тыва.

Photo 3. Adyg-Tyulyush Khemchik-ool with his wife and child. Photo by V. P. Ermolaev, 1928. (SA RT). 


\section{НОВЫЕ ИССЛЕДОВАНИЯ ТУВЫ}

www.nit.tuva.asia

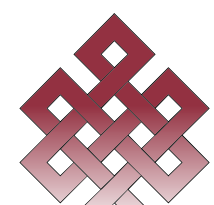

\section{THE NEW RESEARCH OF TUVA}

Novye issledovaniia Tuvy

Среди коллекции особое место занимают фотографии, сделанные в населенных пунктах, запечатлевшие бытовую, общественную, трудовую жизнь тувинцев, портретные и групповые снимки людей. Например, на фотографии, датируемой 1928 г., изображена молодая тувинская семья (фото 3). Благодаря описанию автора, мы знаем, что на фото изображен Адыг-Тюлюш Хемчик-оол Олдукаевич с женой и ребенком, государственный деятель ТНР, расстрелянный в 1938 г. по ложному обвинению (реабилитирован в 1964 г.). На фото также можно увидеть традиционные одежду тувинцев и жилище войлочную юрту кидис өг начала XX в. (Прокофьева, 2011: 288, 307).

На фотографии 1926 г. запечатлён сюжет из повседневной жизни тувинцев - разбивка шерсти, предназначенной для изготовления войлока (фото 4).

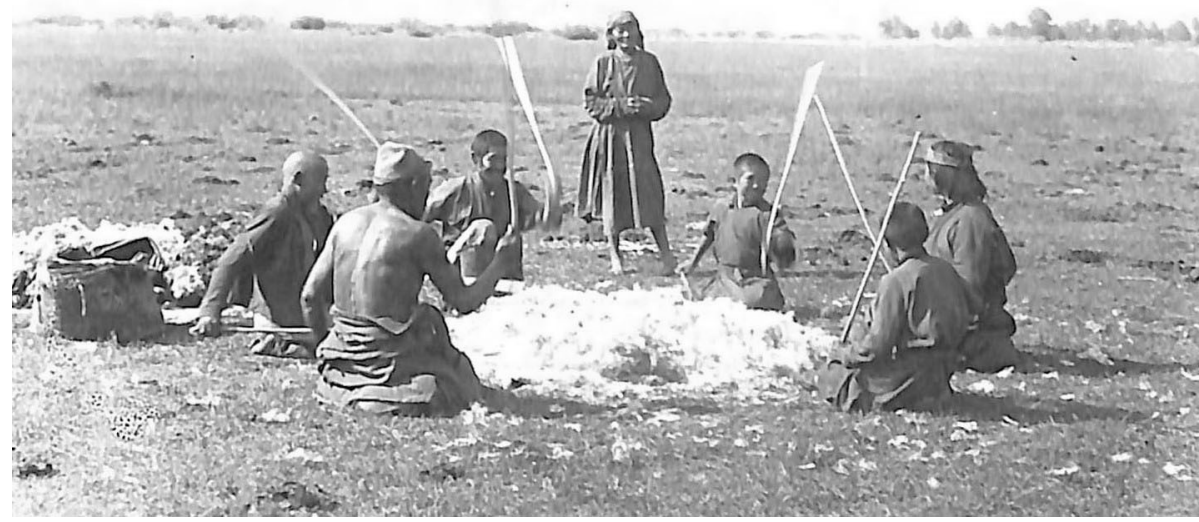

Фото 4. Разбивка шерсти, поселок Ийи-Тал. Фото В. П. Ермолаева, 1928 г.

Из фондов Государственного архива Республики Тыва.

Photo 4. Breaking wool at the village of Iyi Tal. Photo by V. P. Ermolaev, 1928. (SA RT).

На снимке 1936 г. (фото 5) запечатлена сцена борьбы хуреш. Автору удалось передать атмосферу праздника, душевного единства запечатленных лиц: динамику трех борющихся пар, подбадривание помощников судей, зрителей, замерших в радостном ожидании техничной подножки или красивого броска, и последующего за ним грациозного «танца орла» победителей.

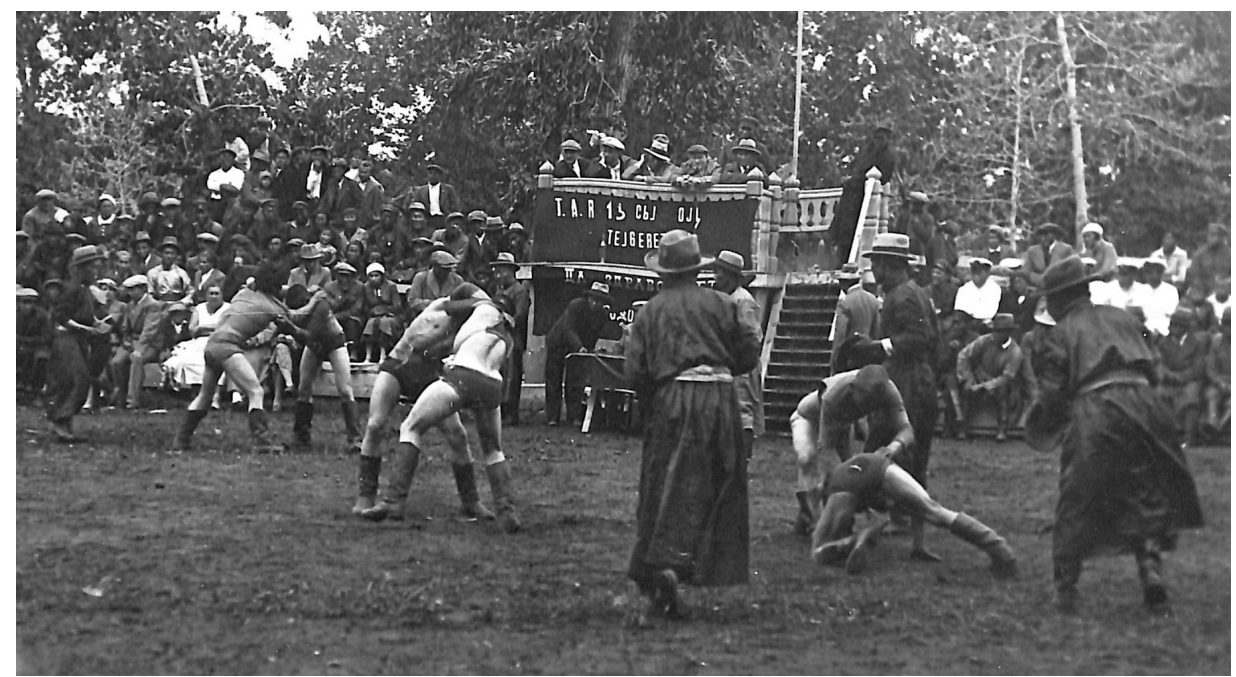

Фото 5. Борьба хуреш. Фото В. П. Ермолаева, 1936 г.

Из фондов Государственного архива Республики Тыва. Photo 5. Huresh wrestlers. Photo by V. P. Ermolaev, 1936. (SA RT). 
В коллекции В. П. Ермолаева имеется серия фотографий с изображениями представителей духовенства, предметов культа, храмов. На фотографии, датируемой 1928 г. (фото 6), запечатлен один из храмов Нижнего хурээ (г. Чадан). Фотографии Ермолаева успели захватить моменты мирной жизни священнослужителей еще до репрессий.

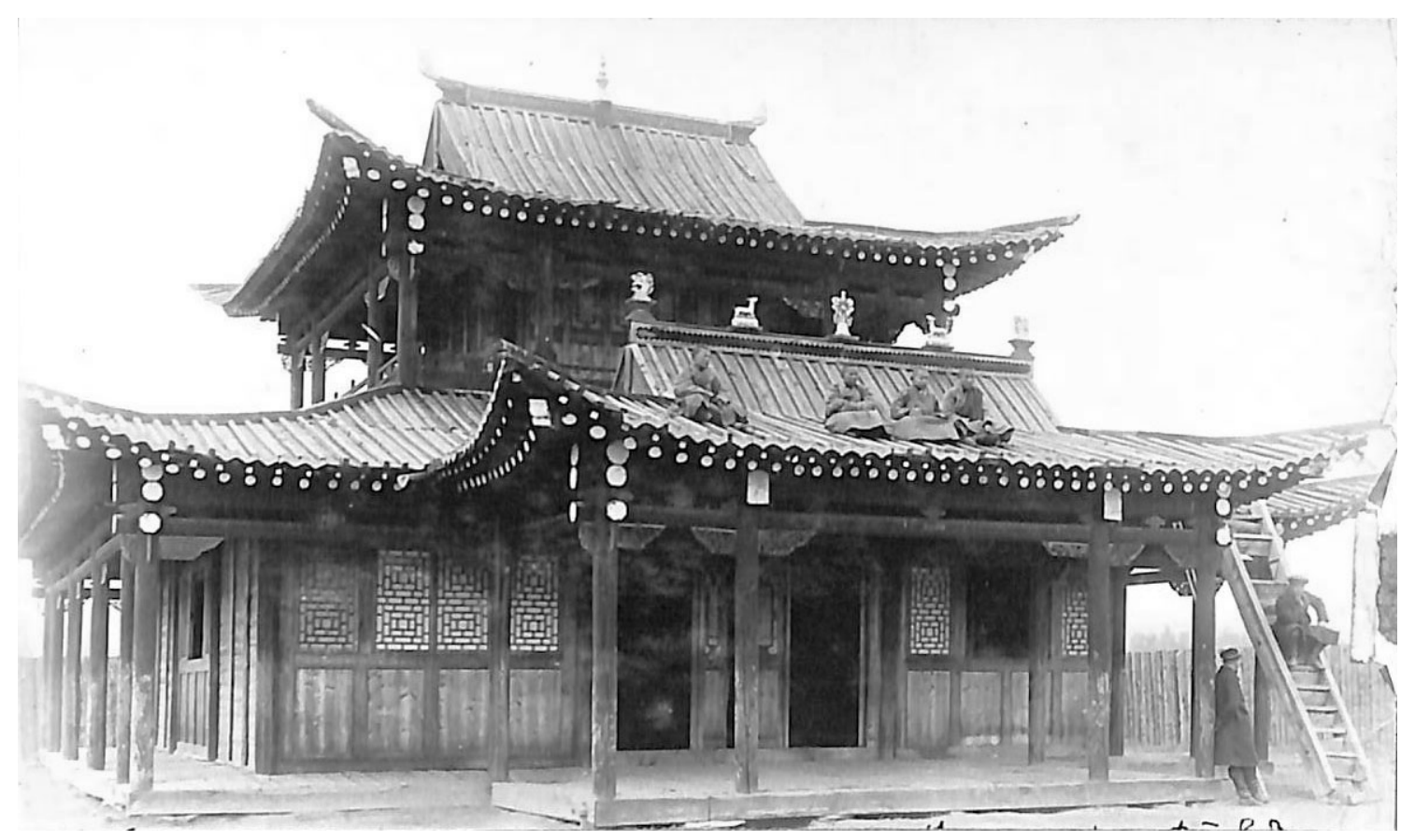

Фото 6. Один из храмов Нижнего хурээ в Чадане. Фото В. П. Ермолаева, 1928 г. Из фондов Государственного архива Республики Тыва. Photo 6. One of the temples of the Lower Khuree in Chadan. Photo by V. P. Ermolaev, 1928. (SA RT).

Таким образом, коллекцию фотодокументов В. П. Ермолаева составляет 1572 фотоотпечатка, они отражают разные аспекты жизни народа и являются богатейшим источником для исследования истории Тувы. И хотя о творчестве В. П. Ермолаева вышло много работ, тем не менее, мы считаем, что оно недостаточно исследовано.

\section{Состав отдельных коллекций фотодокументов}

Фотофонд ГА РТ широко представлен фотодокументами государственных деятелей, рядовых тружеников, а также людей, внесших существенный вклад в развитие республики. К ним относятся фотодокументы следующих коллекций: «Герои социалистического труда» за 1949-1984 гг. (ГА РТ, ф. 20, оп. 1 (ф/д)), «Знатные люди» за 1963-1984 гг. (ГА РТ, ф. 21, оп. 1 (Ф/д)), «Передовики производства периода ТНР» за 1926-1941 гг. (ГА РТ, ф. 22, оп. 1 (ф/д)), «Кавалеры ордена Ленина» за 1971-1984 гг. (ГА РТ, ф. 33, оп. 1 (ф/д)), «Кавалеры ордена Трудового Красного знамени» за 1968-1984 гг. (ГА РТ, ф. 40, оп. 1 (ф/д)), «Победители соцсоревнований Республики Тыва» за 1969-1983 гг. (ГА РТ, ф. 116, оп. 1 (ф/д)), «Передовики и ударники Коммунистического труда» за 1926-1984 гг. (ГА РТ, ф. 122, оп. 1 (ф/д)), «Секретари Тувинского обкома ВЛКСМ, райкомов ВЛКСМ, партийных организаций» за 1948-1981 гг. (ГА РТ, ф. 124, оп. 1 (ф/д)), «Депутаты Верховного Совета Тувинской АССР» за 1970-1978 гг. (ГА РТ, ф. 42, оп. 1 (ф/д)), «Палата представителей Великого Хурала Республики Тыва» за 2007-2010 гг. (ГА РТ, ф. 111, оп. 1 (ф/д)), «Молодежь, комсомол, студенты» за 1942-1997 гг. (ГА РТ, ф. 13, оп. 1 (ф/д)), «Работники МВД республики» за 1971-1979 гг. (ГА РТ, ф. 103, оп. 1 (ф/д)), «Ученые» за 1962-1978 гг. (ГА РТ, ф. 30, оп. 1 (ф/д)), «Заслуженные работники просвещения. Заслуженные учителя» за 1972-1984 гг. (ГА РТ, ф. 46, оп. 1 (ф/д)), «Художники» за 1962-1979 гг. (ГА РТ, ф. 10, оп. 1 (ф/д)), «Артисты тувинского театра» за 1951-1979 гг. (ГА РТ, ф. 14, оп. 1 (ф/д)), «Композиторы» за 1960-1979 гг. (ГА РТ, ф. 16, оп. 1 (ф/д)), «Заслуженные работники здравоохранения» за 1964-1979 гг. (ГА РТ, ф. 35, оп. 1 (Ф/д)) и др. 
В коллекцию «Члены Тувинской народно-революционной партии (ТНРП)» за 1925-1943 гг. (ГА РТ, ф. 1, оп. 1 (ф/д)), вошли негативы и позитивы с изображениями Буяна-Бадарху (Буяна-Бадыргы), видного государственного деятеля, одного из основателей Тувинского государства; Оюна Курседи Кенден оглу, революционера, основателя Тувинской народно-революционной партии; участников IX съезда ТНРП и др.

В фотоколлекциях «Красные партизаны» за 1917-1977 гг. (ГА РТ, ф. 45, оп. 1 (ф/д), «Участники Армейского Совета партизанской армии Кравченко-Щетинкина» за 1918-1968 гг. (ГА РТ, ф. 118, оп. 1 (ф/д)) имеются негативы, позитивы, а также фотокопии с изображениями участников партизанского движения, портретные и групповые: Александра Диомидовича Кравченко - главнокомандующего Крестьянской партизанской армией на юге Енисейской губернии, Петра Ефимовича Щетинкина - помощника командующего партизанской армией, Серго Сургуладзе - председателя Армейского Совета партизанской армии Кравченко-Щетинкина, подхребтинских партизан и партизан Арголика.

Коллекция «Женщины Тувы» за 1930-1977 гг. (ГА РТ, ф. 6, оп. 1 (ф/д)) представлена фотодокументами с изображениями женщин, собраний женорганизаций, женсоветов, конференций съездов. Фотодокументы показывают современникам изменившееся положение женщин в Тувинской Народной Республике, Советской Туве, когда повысилась ее социальная активность.

Разнообразными фотодокументами представлена коллекция «С. К. Тока, первый секретарь Тувинского Обкома КПСС» за 1901-1973 гг. (ГА РТ, ф. 8, оп. 1 (ф/д)). Салчак Калбакхорекович Тока - тувинский советский государственный деятель и писатель. Герой Социалистического Труда (1971 г.); лауреат Сталинской премии третьей степени (1951г.); член ВКП(б) с 1944 г.; член Народно-революционной партии Тувы с 1929 г.; председатель Союза советских писателей Тувы. С 1932 по 1944 гг. являлся первым секретарём ЦК Тувинской Народно-революционной партии (избран на IX съезде ТНРП). После присоединения ТНР к РСФСР и преобразования её в октябре 1944 г. в Тувинскую автономную область в составе РСФСР стал первым секретарём Тувинского областного комитета ВКП(б) и возглавлял партийную организацию Тувы до самой смерти (Салчак Тока, 2015).

В ознаменование 75-летия Победы в Великой Отечественной войне 1941-1945 гг. 2020 год объявлен в Российской Федерации Годом памяти и славы. Вполне конкретную цель перед архивами РФ поставил президент В. В. Путин в ходе обращения к Федеральному собранию 15 января 2020 г. Он сказал, что в России будет создан крупнейший, самый полный комплекс архивных документов, кино- и фотодокументов по Второй мировой войне ${ }^{1}$ Это определяет особую актуальность работы с фотодокументами следующих коллекций: «Тувинские добровольцы - участники Великой Отечественной войны» за 1938-1985 гг. (ГА РТ, ф. 19, оп. 1 (ф/д)), «Ветераны Великой Отечественной войны» $3 а$ 1942-1985 гг. (ГА РТ, ф. 23, оп. 1 (ф/д)), «Участники Великой Отечественной войны 1941-1945 гг.» за 1975-1987 гг. (ГА РТ, ф. 50, оп. 1 (ф/д)) и др. В данных фотоколлекциях представлены негативы и позитивы с изображениями тувинских гвардейцев Сенди-Хуурака Бегзи, Оюна Сырат-оола, Дажимба Данила Чамзыраловича, Чамзырына Кыргыса Шошкуповича, танкистов Кызыл-Таса Михаила Мартыновича, Нурзата Тулюша; наших земляков, удостоившихся звания Героя Советского Союза Хомушку Чургуй-оола Намгаевича, Бухтуева Михаила Артемьевича, Кечил-оола Тулуша Балдановича; Героев Советского Союза, живших и трудившихся в Туве после войны Макаренко Николая Николаевича, Брагина Василия Петровича, Ефимова Леонида Николаевича, Трофимова Николая Игнатьевича и других; тувинских добровольцев, вернушихся домой (фото 7); встреч ветеранов в разные годы; бесед с учениками, студентами, рабочими коллективами. В данные фонды также вошли фотокопии нормативных правовых актов о награждении орденами и медалями, статей из газет о ратных подвигах наших земляков.

Не менее интересны фотодокументы коллекции «Пальмбах Александр Адольфович (1897-1963) тюрколог, один из основателей тувинской письменности» за 1930-1961 гг. (ГА РТ, ф. 47, оп. 1 (ф/д)), переснятые с позитивов-оригиналов фотографом К. Х. Очуром 24 ноября 1987 г. В коллекцию вошли фотокопии с изображениями А. А. Пальмбаха во время проведения занятий по изучению новой тувинской письменности; его выступления на научно-практической конференции, посвященной 30-летию тувинской письменности; групповых снимков в кругу семьи, друзей, коллег: с сыном, кандидатом технических наук Тимуром Александровичем Пальмбахом; с Н. Д. Ажикмаа-Рушевой, Надей Руше-

\footnotetext{
${ }^{1}$ Мисливская, Г. (2020) Путин заявил о создании полного архива документов о Второй мировой войне [Электронный ресурс] // Российская газета. 15 января. URL: https://rg.ru/2020/01/15/putin-v-rossii-poiavitsia-polnyj-arhiv-dokumentov-o-vtorojmirovoj-vojne.html (дата обращения: 20.01.2020).
} 


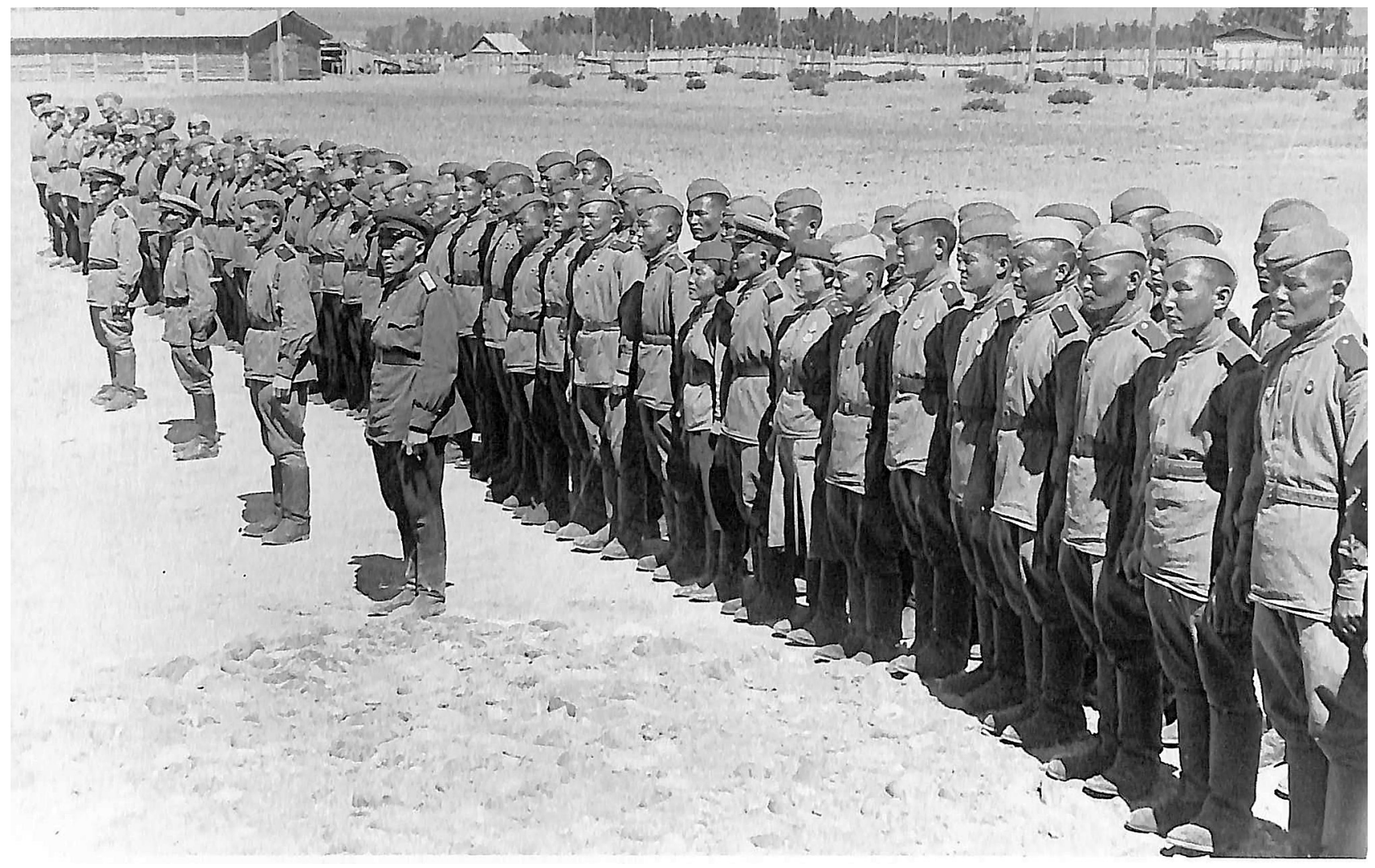

Фото 7. Тувинские добровольцы вернулись с фронта, 1944 г. Автор неизвестен. Из фондов Государственного архива Республики Тыва.

Photo 7. Tuvan volunteers returned from the front, 1944. Author unknown (SA RT).

вой, Ю. Ш. Кунзегешом, О. К. Саган-оолом (в квартире Рушевых); с Л. Б. Чадамба, А. Ч. Кызыл-оолом, А. Б. Чыргал-оолом, внучкой Аллой (в квартире Пальмбаха); с Я. Ш. Хертеком, кандидатом филологических наук, заведующим сектором языка и письменности ТНИИЯЛИ, и информатором Бараан Туменек во время научной командировки в Тоджу и другие.

В декабре 1998 г. фотофонд Государственного архива РТ пополнился фотодокументами Нади Рушевой (1952-1969), советского художника-графика (ГА РТ, ф. 91, оп. 1 (ф/д)). В коллекции имеются фотокопии с запечатленной на них шестимесячной и двухгодовалой Надей; Надей-ученицей 12 и 14 лет, на персональной выставке во Дворце пионеров в г. Москве, на телевизионном голубом огоньке, перед выездом в Ленинград (по приглашению киностудии документальных фильмов).

Фотографии, как известно, - свидетельства подтверждения событий. «Картинка может быть искаженной, но всегда есть основание полагать, что существует или существовало нечто, подобное запечатленному на ней» (Сонтаг, 2013: 15). Для современного исследователя будут интересны фотодокументы, зафиксировавшие события республиканского масштаба, местных «точечных» мероприятий, таких коллекций, как «Церемония открытия буддийского храма - хурээ «Чон-Сөөк» в с. Кызыл-Даг Бай-Тайгинского района Тувинской АССР» за 1990 г. (ГА РТ, ф. 84, оп. 1 (ф/д)), «Приезд Его Святейшества Далай-Ламы XIV Тэнзина Гьяцо в Республику Тыва» за 1992 г. (ГА РТ, ф. 86, оп. 1 (ф/д)), «Церемония вступления в должность Президента Республики Тува и принесение им присяги на внеочередной 15-ой сессии Республики Тува» за 1992 г. (ГА РТ, ф. 87, оп. 1 (ф/д)), «Открытие дома-интерната для ветеранов войны и труда в г. Кызыле» за 1984 г. (ГА РТ, ф. 88, оп. 1 (ф/д)), «Приезд в Туву высокопоставленных лиц» за 1998-2000 гг. (ГА РТ, ф. 97, оп. 1 (ф/д)), «Открытие нового моста через реку Каа-Хем» за 1999 г. (ГА РТ, ф. 106, оп. 1 (ф/д)); «Тува в фотографиях. К 50-летию образования ТНР» за 1971 г. (ГА РТ, ф. 110 , оп. 1 (ф/д)).

Авторами фотодокументов или отдельных коллекций являются известные в фотографической среде Тувы и за ее пределами мастера. Такие, как ушедшие из жизни Владимир Петрович Ермолаев, Анатолий Иванович Мельников, Ондар Дукурович Охемчик, Юрий Алексеевич Косарьков, Владимир Федорович Чадамба, и ныне здравствующие Владимир Никандрович Савиных, Виталий Андреевич Шайфулин 
и другие. Фотодокументы под их авторством при передаче в архив сопровождались аннотациями и, в некоторых случаях, - текстовыми сопроводительными документами в виде репортажей, статей. Это позволило нам донести до современного исследователя информационные функции фотодокументов и существенно улучшило их дальнейшее применение в архивной работе.

Использование фотодокументов предполагает разные формы, одной из которых является публикация. Государственным архивом Республики Тыва подготовлены и выпущены в свет печатные издания, в которых есть фотодокументы (Тува в годы Великой ..., 2005; Россия и Тува ..., 2004; История города ..., 2009, 2012; Мы будем жить ..., 2010; История ..., 2011; Ты врага ..., 2013; На перекрестке ... , 2014; История Даа кожууна, 2015; Война ..., 2015 и др.).

Для издания фотодокументов необходимо проводить грамотное археографическое оформление (Абилова, 2015: 94). А именно, как пишет В. П. Козлов, необходимо выделить идентификацию - человек, место, время; при публикации групповых фотографий желательно не только персонифицировать каждого человека, но и представить его краткие биографические сведения (Козлов, 2008: 144). Поэтому для публикаций архив использует наиболее аннотированные фотодокументы, тщательно перепроверяя достоверность информации. Данный подход используется и при подготовке стационарных и электронных выставок, при размещении фотодокументов на официальном сайте учреждения (http:// gosarhivrt.ru/), в социальных сетях «ВКонтакте» (https://m.vk.com/tuvaarch), Facebook (https://www. facebook.com/tuvaarch), Instagram (https://www.instagram.com/tuvaarch/).

\section{Заключение}

Фотофонд Государственного архива Республики Тыва является важным источником изучения истории республики, который сохранил изображения объектов, исторических событий и людей. Поэтому работа архива с фотодокументами является одним из главных направлений деятельности. Однако, выполняются не все необходимые задачи. Например, в нескольких фондах осталась неучтенной часть негативов. Для точного выявления количества единиц хранения необходимо провести проверку наличия этих фондов и внести изменения в учетные документы.

Следует вынести на рассмотрение экспертно-проверочной комиссии Министерства культуры РТ вопрос о внесении коллекции фотодокументов В. П. Ермолаева за 1913-1940 гг. в Государственный реестр уникальных документов Республики Тыва. Необходимо также провести повторную оцифровку 1572 фотоотпечатков данной коллекции на современном сканирующем устройстве.

С приобретением профессионального фотоаппарата и объектива к нему необходимо усилить работу по инициативному документированию.

В перспективе следует провести оцифровку всего фотофонда ГА РТ и внести в базу данных программно-информационного комплекса «КАИСА-Архив», разработанного компанией «Альт-Софт», г. Санкт-Петербург. Оцифрованный фотофонд, внесенный в электронную базу данных, будет доступен любому пользователю сети Интернет через модуль «Электронный читальный зал» на официальном сайте архива.

Коллекция фотодокументов ГА РТ может быть использована в различных проектах, посвященных изучению истории Тувы и ее культуры.

Отдельной, еще не решенной проблемой, является проблема отслеживания соблюдения авторских прав на фотодокументы, которая встала особенно остро в связи с многократным порой тиражированием изображений в Интернете. Сам архив с недавних пор стал ставить водяные знаки на иллюстрации, выкладываемые на своих ресурсах. Но проблема пиратства требует системного подхода.

\section{СПИСОК ЛИТЕРАТУРЫ}

Абилова Р. О. (2015) Проблемы изучения фотодокумента как объекта архивоведения в российской историографии (2000-е годы) [Электронный ресурс] // Ученые записки Казанского университета. Серия Гуманитарные науки. T. 157, кн. 3. C. 89-97. URL: https://kpfu.ru/portal/docs/F244353010/157_3_gum_10.pdf (дата обращения: 27.11.2019).

Айыжы, Е. А., Мандан-Хорлу, М. М., Монгуш, А. Ч. (2019а) История создания коллекции В. П. Ермолаева как части этнографического источника изучения материальной и духовной культуры тувинского этноса (часть 1 ) // Oriental Studies. № 4. C. 669-681. DOI: https://doi.org/10.22162/2619-0990-2019-44-4-669-681

Айыжы, Е. А., Мандан-Хорлу, М. М., Монгуш, А. Ч. (2019b) История создания коллекции В. П. Ермолаева как 
части этнографического источника изучения материальной и духовной культуры тувинского этноса (часть 2 ) // Oriental Studies. № 5. C. 926-937. DOI: https://doi.org/10.22162/2619-0990-2019-45-5-926-937

Владимир Петрович Ермолаев - очевидец великих перемен : избранные работы (2012) / отв. за вып. В. С. Чигжит. Кызыл : КЦО «Аныяк». 196 с.

Война далекая и близкая : сборник архивных документов (2015) / ред. кол. : А. М. Дугар-Сюрюн [и др.]. Новосибирск : Сибирское книжное издательство. 256 с.

Дугар-Сюрюн, А. М. (2013) История Республики Тыва в архивных фотодокументах очевидца В. П. Ермолаева // Первые республиканские Ермолаевские краеведческие чтения : сборник материалов конференции / отв. за вып. В. С. Чигжит. Кызыл : КЦО «Аныяк». 240 с. С. 18-22.

Дыртык-оол, А. О. (2012) Владимир Петрович Ермолаев [Электронный ресурс] // Новые исследования Тувы. № 4. URL: https://nit.tuva.asia/nit/article/view/291 (дата обращения: 14.12.2019).

Дыртык-оол, А. О. (2013) Исторические фотографии В. П. Ермолаева в коллективных монографиях Тувы // Первые республиканские Ермолаевские краеведческие чтения : сборник материалов конференции / отв. за вып. В. С. Чигжит. Кызыл : КЦО «Аныяк». 240 с. С. 38-41.

Дыртык-оол, А. О. (2019) Тувинский театр в фотографиях В. П. Ермолаева // Ермолаевские чтения : материалы III научно-практической конференции / отв. ред. А. К. Тамдын. Кызыл : МБОУ КЦО «Аныяк». 256 с. С. $180-184$.

Дыртык-оол, М. О. (2013) К вопросу о научном описании фотоматериалов В. П. Ермолаева // Первые республиканские Ермолаевские краеведческие чтения : сборник материалов конференции / отв. за вып. В. С. Чигжит. Кызыл : КЦО «Аныяк». 240 с. С. 65-67.

Иргит, О. Ю. (2019) Фотографии В. П. Ермолаева как важный исторический источник о репрессиях в Туве // Ермолаевские чтения : материалы III научно-практической конференции / отв. ред. А. К. Тамдын. Кызыл : МБОУ КЦО «Аныяк». 256 с. С. 176-180.

История Даа кожууна : научно-популярный сборник (2015) / ред. кол. : А. М. Дугар-Сюрюн, Б. Н. Монгуш. Новосибирск : ООО «Сибирское книжное издательство». 320 с.

История города в Центре Азии : сборник документов за 1914-1944 гг. (2009) / ред. кол. : Р. М. Арчимаева [и др.]. Новосибирск : Новосибирское книжное издательство. Т. 1. 232 с.

История города в Центре Азии : сборник документов за 1944-1961 гг. (2012) / ред. кол. : А. М. Дугар-Сюрюн [и др.]. Новосибирск : Сибирское книжное издательство. Т. 2. 240 с.

История Тувинской Народной Республики в архивных документах. 1921-1944 гг. (2011) / ред. кол. : А. М. ДугарСюрюн [и др.]. Новосибирск : Сибирское книжное издательство. 312 с.

Козлов, В. П. (2008) Основы теоретической и прикладной археографии. М. : РОССПЭН. 224 с.

Кушнаренко, Н. Н. (2006) Документоведение. Киев : Знання. 459 с.

Ларьков, Н. С. (2006) Документоведение : в 2 ч. М. : Изд-во АСТ. Ч. 1. 72 с. С. 37-38.

Магидов, В. М. (1992) Кинофотофонодокументы как исторический источник // Отечественная история. № 5. C. 104-116.

Мандан-Хорлу, М. М. (2019) Каа-Хемский кожуун Республики Тыва по фотографиям В. П. Ермолаева // Ермолаевские чтения : материалы III научно-практической конференции / отв. ред. А. К. Тамдын. Кызыл : МБОУ КцО «Аныяк». 256 с. С. 190-193.

Мандральская, Н. В. (2010) Принципы научной классификации в определении методики источниковедческого анализа кино- фото- фонодокументов // Вестник архивиста. № 2. С. 255-269.

Молеров, Н. М., Март-оол, В. Д. (2013) «Урянхайский вопрос» в политической истории России: возникновение и долговременная актуальность. Абакан : ООО «Кооператив «Журналист». 244 с.

Монгуш, О. О. (2013) Фотографии В. П. Ермолаева как исторический источник // Первые республиканские Ермолаевские краеведческие чтения : сборник материалов конференции / отв. за вып. В. С. Чигжит. Кызыл : КЦО «Аныяк». 240 с. С. 41-44.

Мунге, Б. В. (2019) Фотографии В. П. Ермолаева в фондах Государственного архива Республики Тыва: состав и использование // Ермолаевские чтения : материалы III научно-практической конференции / отв. ред. А. К. Тамдын. Кызыл : МБОУ КЦО «Аныяк». 256 с. Ермолаевские чтения : материалы III научно-практической конференции / отв. ред. А. К. Тамдын. Кызыл : МБОУ КЦО «Аныяк». 256 с. С. 153-156.

Мы будем жить в коротком слове - Память : сборник документов о Великой Отечественной войне 1941-1945 гг. (2010) / ред. кол. : А. М. Дугар-Сюрюн [и др.]. Новосибирск : Сибирское книжное издательство. 208 с.

На перекрестке времени : сборник архивных документов и фотодокументов (2014) / ред. кол. : А. М. Дугар-Сюрюн [и др.]. Новосибирск : Сибирское книжное издательство. 480 с.

Прокофьева, Е. Д. (2011) Процесс национальной консолидации тувинцев. СПб. : Наука. Т. 4.538 с.

Россия и Тува - вместе 60 лет : сборник архивных документов (2004) / ред. кол. : Д. И. Чыдым, Т. С. Саая, 
Т. А. Бондаренко. Кызыл : Типография Госкомитета по печати и информации Республики Тыва. 56 с.

Салчак Тока (2015) / Донгак У. А., Канзай А. К. Кужугет М. А., Моллеров Н. М., Ооржак Д. К.-Х., Самдан А. А., Самдан 3. Б, Ширшин Г. Ч.; отв. ред. К. А. Бичелдей. М. : Слово. 543 с.

Сонтаг, С. (2013) О фотографии / пер. с англ. Виктора Голышева. М. : Ад Маргинем Пресс. 272 с.

Тува в годы Великой Отечественной войны в документах : сборник документов, фотографий, писем (2005) / ред. : А. С. Казанцева. Кызыл : Тувинское книжное издательство. 232 с.

Ты врага переспорил в бою... : сборник документов, статей из газет к 70-летию оправки на фронт тувинских добровольцев (2013) / гл. ред. : А. М. Дугар-Сюрюн. Кызыл : КЦО «Аныяк». 72 с.

Дата поступления: 01.02.2020 г.

\section{REFERENCES}

Abilova R. O. (2015) Problemy izucheniia fotodokumenta kak ob’ekta arkhivovedeniia v rossiiskoi istoriografii (2000e gody) [Researching photo documents as an object of archival studies in Russian historiography in the 2000s]. Uchenye zapiski Kazanskogo universiteta. Seriia Gumanitarnye nauki, vol. 157, book 3, pp. 89-97 [online] Available at: https://kpfu. ru/portal/docs/F244353010/157_3_gum_10.pdf (access data: 12.10.2019). (In Russ.).

Aiyzhy, E. A., Mandan-Khorlu, M. M. and Mongush, A. Ch. (2019a) Istoriia sozdaniia kollektsii V. P. Ermolaeva kak chasti etnograficheskogo istochnika izucheniia material'noi i dukhovnoi kul'tury tuvinskogo etnosa (chast' 1) [V. P. Ermolaev's collection as an ethnographic source for studies of Tuvan material and spiritual culture. Part 1]. Oriental Studies, no 4, pp. 669-68. DOI: https://doi.org/10.22162/2619-0990-2019-44-4-669-681 (In Russ.).

Aiyzhy, E. A., Mandan-Khorlu, M. M., Mongush, A. Ch. (2019b) Istoriia sozdaniia kollektsii V. P. Ermolaeva kak chasti etnograficheskogo istochnika izucheniia material'noi i dukhovnoi kul'tury tuvinskogo etnosa (chast' 2) [V. P. Ermolaev's collection as an ethnographic source for studies of Tuvan material and spiritual culture. Part 2]. Oriental Studies. no 5, pp. 926-93. DOI: https://doi.org/10.22162/2619-0990-2019-45-5-926-937 (In Russ.).

Vladimir Petrovich Ermolaev - ochevidets velikikh peremen [Vladimir Petrovich Ermolaev as a witness of historic changes] (2012) : Selected works / ed. by V. S. Chigzhit. Kyzyl, KTsO «Anyiak». 196 p. (In Russ.).

Voina dalekaia i blizkaia [The war, far and near] : A collection of archival documents (2015) / eds.: A. M. Dugar-Siuriun et al. Novosibirsk, Sibirskoe knizhnoe izdatel'stvo. 256 p. (In Russ.).

Dugar-Surun, A. M. (2013) Istoriia Respubliki Tyva v arkhivnykh fotodokumentakh ochevidtsa V. P. Ermolaeva [The history of the Republic of Tuva in archival photo documents of eyewitness V. P. Ermolaev]. In: Pervye respublikanskie Ermolaevskie kraevedcheskie chteniia [1st Ermolaev readings in local history, Republic of Tuva] : conference proceedings / ed. by V. S. Chigzhit. Kyzyl, KTsO «Anyiak». 240 p. Pp. 18-22. (In Russ.).

Dyrtyk-ool, A. O. (2012) Vladimir Petrovich Ermolaev. The New Research of Tuva, no. 4 [online] Available at: https://nit. tuva.asia/nit/article/view/291 (access data: 14.12.2019). (In Russ.).

Dyrtyk-ool, A. O. (2013) Istoricheskie fotografii V. P. Ermolaeva v kollektivnykh monografiiakh Tuvy [Historical photographs by V. P. Ermolaev in collective monographs published in Tuva]. In: Pervye respublikanskie Ermolaevskie kraevedcheskie chteniia [1st Ermolaev readings in local history, Republic of Tuva] : conference proceedings / ed. by V. S. Chigzhit. Kyzyl, KTsO «Anyiak». 240 p. Pp. 38-41. (In Russ.).

Dyrtyk-ool, M. O. (2013) K voprosu o nauchnom opisanii fotomaterialov V. P. Ermolaeva [On the issue of scholarly description of photographic materials by V. P. Ermolaev]. In: Pervye respublikanskie Ermolaevskie kraevedcheskie chteniia [1st Ermolaev readings in local history, Republic of Tuva] : conference proceedings / ed. by V. S. Chigzhit. Kyzyl, KTsO «Anyiak». 240 p. Pp. 65-67. (In Russ.).

Dyrtyk-ool, A. O. (2019) Tuvinskii teatr v fotografiiakh V. P. Ermolaeva [Tuvan theater in the photographs by V. P. Ermolaev]. In: Ermolaevskie chteniia [Ermolaev readings] : proceedings of the 3rd conference / ed. by A. K. Tamdyn. Kyzyl, MBOU KTsO «Anyiak». 256 p. Pp. 180-184. (In Russ.).

Irgit, O. Yu. (2019) Fotografii V. P. Ermolaeva kak vazhnyi istoricheskii istochnik o repressiiakh v Tuve [Photographs by V. P. Ermolaev as an important historical source on purges in Tuva]. In: Ermolaevskie chteniia [Ermolaev readings] : proceedings of the 3rd conference / ed. by A. K. Tamdyn. Kyzyl, MBOU KTsO «Anyiak». 256 p. Pp. 176-180. (In Russ.).

Istoriia Daa kozhuuna [The History of Daa Kozhuun] (2015): A Popular Science Collection / eds.: A. M. Dugar-Siuriun, B. N. Mongush. Novosibirsk, Sibirskoe knizhnoe izdatel'stvo. 320 p. (In Russ.).

Istoriia goroda $v$ Tsentre Azii [History of the city in the center of Asia] (2009) : a collection of documents, 1914-1944 / eds.: R. M. Archimaeva et al. Novosibirsk, Novosibirskoe knizhnoe izdatel'stvo. Vol. 1232 p. (In Russ.).

Istoriia goroda $v$ Tsentre Azii [History of the city in the Center of Asia] (2012): a collection of documents, 1944-1961 / eds.: A. M. Dugar-Surun et al. Novosibirsk, Sibirskoe knizhnoe izdatel'stvo. Vol. 2240 p. (In Russ.).

Istoriia Tuvinskoi Narodnoi Respubliki v arkhivnykh dokumentakh. 1921-1944 gg. [History of the Tuvan People's 
Republic in archival documents, 1921-1944] (2011) / eds.: A. M. Dugar-Siuriun et al. Novosibirsk, Sibirskoe knizhnoe izdatel'stvo. 312 p. (In Russ.).

Kozlov, V. P. (2008) Osnovy teoreticheskoi i prikladnoi arkheografii [Fundamentals of theoretical and applied archaeography]. Moscow, ROSSPEN. 224 p. (In Russ.).

Kushnarenko, N. N. (2006) Dokumentovedenie [Document studies]. Kiev, Znannia. 459 p. (In Russ.).

Lar'kov, N. S. (2006) Dokumentovedenie [Document studies] : in 2 parts. Moscow, AST. Part 1. 72 p. Pp. 37-38. (In Russ.).

Magidov, V. M. (1992) Kinofotofonodokumenty kak istoricheskii istochnik [Cinema and photo documents as a historical source]. Otechestvennaia istoriia, no. 5, pp. 104-116. (In Russ.).

Mandan-Khorlu, M. M. (2019) Kaa-Khemskii kozhuun Respubliki Tyva po fotografiiam V. P. Ermolaeva [Kaa-Khem kozhuun of the Republic of Tuva in the photographs by V. P. Ermolaev]. In: Ermolaevskie chteniia [Ermolaev readings] proceedings of the 3rd conference / ed. by A. K. Tamdyn. Kyzyl, MBOU KTsO «Anyiak». 256 p. Pp. 190-193. (In Russ.).

Mandral'skaia, N. V. (2010) Printsipy nauchnoi klassifikatsii v opredelenii metodiki istochnikovedcheskogo analiza kino- foto- fonodokumentov [The principles of scientific classification in determining the methodology of source study analysis of video-, photo-, and phonodocuments]. Vestnik arkhivista. no. 2, pp. 255-269. (In Russ.).

Molerov, N. M. and Mart-ool, V. D. (2013) «Uriankhaiskii vopros» v politicheskoi istorii Rossii: vozniknovenie $i$ dolgovremennaia aktual'nost' [The "Uriankhai issue" in the political history of Russia, its emergence and long-term relevance]. Abakan, Kooperativ «Zhurnalist». 244 p. (In Russ.).

Mongush O. O. (2013) Fotografii V. P. Ermolaeva kak istoricheskii istochnik [Photos by V. P. Ermolaev as a historical source]. In: Pervye respublikanskie Ermolaevskie kraevedcheskie chteniia [1st Ermolaev readings in local history, Republic of Tuva] : conference proceedings / ed. by V. S. Chigzhit. Kyzyl, KTsO «Anyiak». 240 p. Pp. 41-44. (In Russ.).

Munge, B. V. (2019) Fotografii V. P. Ermolaeva v fondakh Gosudarstvennogo arkhiva Respubliki Tyva: sostav i ispol'zovanie [Photos by V.P. Ermolaev in the collections of the State Archives of the Republic of Tuva: composition and use]. In: Ermolaevskie chteniia [Ermolaev readings] : proceedings of the 3rd conference / ed. by A. K. Tamdyn. Kyzyl, MBOU KTsO «Anyiak». 256 p. Pp. 153-156. (In Russ.).

My budem zhit' $v$ korotkom slove - Pamiat' [We will live in a short word - Memory] : a collection of documents on the Great Patriotic War, 1941-1945 (2010) / eds.: A. M. Dugar-Siuriun et al. Novosibirsk, Sibirskoe knizhnoe izdatel'stvo. 208 p. (In Russ.).

Na perekrestke vremeni [At the crossroads of time] : a collection of archival documents and photo documents (2014) / eds.: A. M. Dugar-Surun et al. Novosibirsk, Sibirskoe knizhnoe izdatel'stvo. 480 p. (In Russ.).

Prokof'eva, E. D. (2011) Protsess natsional'noi konsolidatsii tuvintsev [The Process of National Consolidation of the Tuvans]. St. Petersburg, Nauka. 538 p. (In Russ.).

Rossiia i Tuva - vmeste 60 let [Russia and Tuva - 60 years together] (2004): a collection of archival documents / eds.: D. I. Chydym, T. S. Saaia, T. A. Bondarenko. Kyzyl, Tipografiia Goskomiteta po pechati i informatsii Respubliki Tyva. 56 p. (In Russ.).

Salchak Toka (2015) / Dongak U. A., Kanzai A. K. Kuzhuget M. A., Mollerov N. M., Oorzhak D. K.-Kh., Samdan A. A., Samdan Z. B. and Shirshin G. Ch. ed. by K. A. Bicheldei. Moscow, Slovo. 543 p.

Sontag, S. (2013) O fotografii [On photography] / transl. from Engl. by Victor Golyshev. Moscow, Ad Marginem Press. 272 p. (In Russ.).

Tuva v gody Velikoi Otechestvennoi voiny v dokumentakh [Tuva during the Great Patriotic War in documents] (2005): a collection of documents, photographs, letters / ed. by A. S. Kazantseva. Kyzyl, Tuvinskoe knizhnoe izdatel'stvo. 232 p. (In Russ.).

Ty vraga peresporil $v$ boiu... [You had the last word over the enemy in battle...] (2013): a collection of documents and newspaper articles on the 70th anniversary of the departure of Tuvan volunteers to the battle line / ed. by A. M. DugarSurun. Kyzyl, KTsO «Anyiak». 72 p. (In Russ.).

Submission date: 01.02.2020. 